\title{
Anomaliile oculare congenitale minore ca markeri somatici în patologia genetică
}

\author{
Iulia-Andrada Nemeș-Drăgan, Ana-Maria Drăgan, Marius Bembea \\ Facultatea de Medicină şi Farmacie, Universitatea din Oradea, România
}

\begin{abstract}
REZUMAT
Introducere. Anomaliile oculare congenitale minore (ACOM) constituie markeri importanţi în detectarea anumitor afecţiuni genetice. Aceştia sunt diverşi ca localizare, număr sau intensitate de exprimare, chiar în cadrul aceleiaşi afecţiuni. Identificarea lor şi, mai ales, interpretarea corectă a acestora sunt esenţiale pentru diagnosticarea precoce a unui pacient cu boală genetică.

Scop. Scopul studiului este reprezentat de analiza ACOM în sindroamele genetice, prin identificarea principalelor morfotipuri de ACOM, precum şi analiza sindroamelor genetice care se asociază cu acestea.

Material şi metodă. A fost realizat un studiu prospectiv pe un lot de 118 pacienţi în perioada februarie 2015 - februarie 2019 cu boli genetice care asociază şi AC oculare. S-a efectuat o examinare oftalmologică amănunţită atât la nivelul anexelor, cât şi la nivelul globului ocular.

Rezultate. Din totalul de 118 pacienţi, $84(71 \%)$ au prezentat malformaţii minore cu sau fără malformaţii majore asociate. Cele mai frecvente anomalii oculare minore au fost întâlnite la nivelul pleoapelor, irisului şi retinei, iar sindromul Down este cel mai frecvent asociat cu anomalii oculare minore.

Concluzii. Anomaliile oculare congenitale minore, chiar dacă nu sunt de gravitate, constituie deseori elemente sugestive pentru anumite sindroame genetice. Indiferent de boala genetică, din punct de vedere anatomic, pleoapa a fost anexa globului ocular care ne-a oferit mereu indicii „minore“ cu un important răsunet diagnostic.
\end{abstract}

Cuvinte cheie: anomalii minore, markeri, boală genetică

\section{INTRODUCERE}

Anomalia congenitală minoră (ACM) se referă la orice modificare somatică, a oricărui organ, care nu produce tulburări funcţionale semnificative, nu are nicio importanţă medicală sau cosmetică şi care nu necesită tratament.

Ochiul este al doilea cel mai afectat organ în bolile genetice, după creier [1]. Incidenţa globală a malformaţiilor congenitale oculare este de 6 la 10.000 de nou-născuţi vii [2]. Bolile sau defectele congenitale oculare sunt, de cele mai multe ori, malformaţii minore şi, aparent, disparate. Ele sunt caracterizate prin modificări anatomice care interesează morfologia anumitor structuri ale globului ocular şi ale anexelor sale. Prezenţa lor la naştere poate semnaliza un sindrom ocular de cauză genetică.

Medicul oftalmolog este adesea confruntat cu o patologie cu simptomatologie complexă, de aceea, examenul clinic amănunţit al acestor pacienţi este foarte important, în scopul identificării altor anomalii, precum şi pentru recunoaşterea unor eventuale asocieri specifice în anumite sindroame genetice.

Anomaliile congenitale minore (ACM) constituie markeri importanţi în detectarea anumitor afecţiuni genetice. Aceştia sunt diverşi ca localizare, număr sau intensitate de exprimare, chiar în cadrul aceleiaşi afecţiuni [3]. Majoritatea ACM sunt localizate la nivelul feţei şi al mâinilor şi apar în perioada incipientă a embriogenezei. O analiză corectă a acestora se realizează în funcţie de criterii rasiale, etnice şi de istoricul familial al pacientului [4]. Identificarea unei malformaţii minore impune evaluarea tuturor organelor dezvoltate în aceeaşi perioadă embriogenetică [5]. Detectarea ACM şi, mai ales, interpretarea corectă a acestora sunt esenţiale pentru diagnosticarea precoce a unui pacient cu boală genetică.

\section{IPOTEZA DE LUCRU}

Bolile genetice se pot asocia cu anumite anomalii specifice ochiului. Identificarea malformaţiilor mi- 
nore prezente la nivelul ochiului poate facilita stabilirea unui diagnostic de sindrom.

\section{SCOPUL STUDIULUI}

Studiul şi-a propus analiza anomaliilor congenitale oculare minore (ACOM) în sindroamele genetice.

Obiective:

1. Identificarea morfotipurilor de ACOM

2. Analiza sindroamelor genetice care asociază ACOM

\section{MATERIAL ŞI METODĂ}

A fost realizat un studiu prospectiv pe un lot de 118 pacienţi cu boli genetice care asociază şi AC oculare recrutaţi din baza de date a Departamentului de Genetică al Spitalului Clinic Municipal „Dr. Gavril Curteanu“ din Oradea.

Studiul a fost efectuat în perioada februarie 2015 februarie 2019 şi a fost aprobat de către Consiliul Etic al spitalului. Pentru fiecare pacient luat în studiu, s-a cerut şi s-a obţinut consimţământul informat al părinţilor sau al pacientului.

Criteriile de includere în studiu au fost:

- pacienţi cu diagnostic cert de boală genetică

- asocierea în contextul bolii genetice a cel puţin unei ACOM

- consult oftalmologic de specialitate, asigurat fie personal, fie de către un alt medic specialist

Criteriile de excludere:

- anomalii oculare dobândite

- pacienţi insuficient de cooperanţi

Examenul clinic oftalmologic a inclus inspecţia şi examenul biomicroscopic al anexelor. La fiecare pacient, s-a măsurat cu rigla distanţa intercantală şi cea interpupilară, necesare pentru a stabili diagnosticul de hipertelorism sau cel de telecantus.

Fisura palpebrală verticală s-a măsurat folosind indicele cornee margine liberă superioară sau pupilă margine liberă superioară. $\mathrm{Cu}$ ajutorul biomicroscopului, s-au examinat marginea liberă anterioară şi inserţia cililor şi marginea liberă posterioară cu glandele meibomiene. Conjunctiva şi punctele lacrimale s-au inspectat iniţial într-o cameră bine luminată, prin eversia pleoaopei inferioare, iar ulterior prin magnificare la biomicroscop.

Examinarea globului ocular s-a efectuat dinspre anterior spre posterior, adică de la cornee la retină, prima dată în mioză, iar, ulterior, în midriază.

Înainte de instilarea midriaticelor, s-au examinat reflexul pupilomotor direct şi consensual şi forma aperturii pupilare. Irisul a fost analizat pe toată circumferinţa şi grosimea sa. De asemenea, s-au anali- zat marginea pupilară, guleraşul pupilar şi periferia iriană.

După instilarea unei picături de tropicamidă 1\%, s-au examinat cristalinul, polul posterior şi vitrosul. Examinarea polului posterior s-a efectuat cu lentila de 90 DP şi biomicroscopul, acolo unde complianţa a fost corespunzătoare, sau cu oftalmoscopul (Heine). S-au evaluat nervul optic, macula, periferia retiniană şi vasele retiniene, care au fost urmărite de la emergenţă spre periferie.

\section{REZULTATE}

Lotul cuprinde pacienţi cu vârstele cuprinse între 1 an şi 65 de ani, provenind din mediul rural şi urban al judeţului Bihor, în proporţii sensibil egale între sexul masculin şi cel feminin.

Majoritatea pacienţilor incluşi în studiu, 51 (43\%), au avut vârsta mai mare de 15 ani, 35 de pacienţi $(30 \%)$ au avut vârsta cuprinsă între 0 şi 7 ani, iar 32 de pacienţi (27\%) au fost cu vârsta cuprinsă între 7 şi 15 ani.

Am examinat un număr de 118 de pacienţi, dintre care $74(62 \%)$ erau diagnosticaţi cu o anomalie cromozomială, $27 \mathrm{cu}$ o boală autozomal dominantă $(22 \%), 9$ cazuri $(7 \%)$ cu o boală autozomal recesivă şi 8 cazuri $(6 \%)$ cu o boală legată de X.

Malformaţiile oculare minore sunt sistematizate în tabelul 1.

TABEL 1. Distribuția anatomică a malformațiilor oculare minore

\begin{tabular}{|l|c|c|}
\hline Organ & Nr. cazuri & $\%$ \\
\hline Pleoapele & & \\
\hline - hipotelorism & 30 & 25 \\
\hline - hipertelorism & 2 & 2 \\
\hline - epicant & 55 & 47 \\
\hline - ptoză & 2 & 2 \\
\hline - fante palpebrale oblice & 77 & 65 \\
\hline Irisul & & \\
\hline Petele Brushfield & 19 & 16 \\
\hline Nodulii Lisch & 5 & 4 \\
\hline Retina & & \\
\hline Vasele supranumerare & 5 & 4 \\
\hline
\end{tabular}

Cele mai frecvente anomalii oculare minore au fost prezente la nivelul anexelor oculare, mai exact, pleoapa a fost cel mai adesea malformată. Astfel cei mai mulţi pacienţi examinaţi au prezentat fante palpebrale oblice, 77 (65\%), 50 (47\%) au prezentat epicant, $30(25 \%)$ au prezentat hipotelorism, 2 (2\%) pacienţi au prezentat ptoză, iar $2(2 \%)$ hipertelorism. Structura oculară cel mai frecvent afectată care ne-a oferit indicii minore pentru diagnostic a fost irisul. Marea majoritate a pacienţilor, 99 (84\%), au prezen- 
tat iris de culoare închisă. Petele Brushfield au fost prezente la 19 dintre pacienţi (16\%), iar nodulii Lisch - la 5 pacienţi (4\%) (Figura 1).
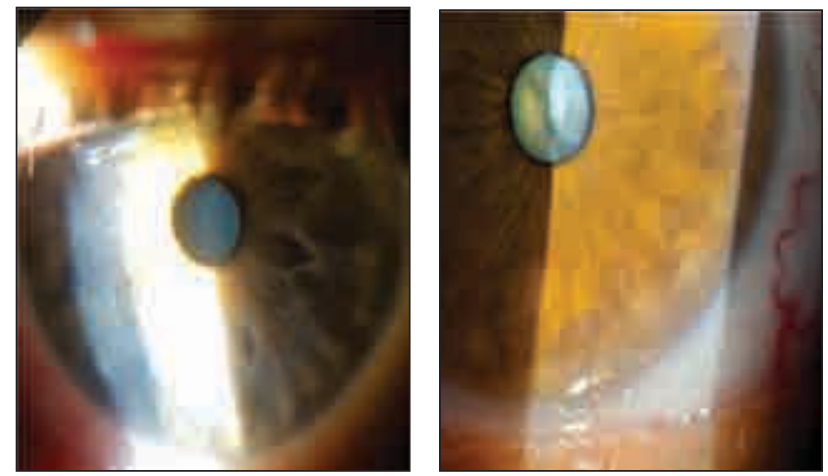

A

B

FIGURA 1. Malformații iriene minore. A. Petele Brushfield. B. Nodulii Lisch

La nivelul polului posterior, s-au observat la 5 pacienţi (4\%) vase supranumerare, cu aspect ,în spiţă de roată“".

Din totalul de 118 pacienţi, 84 (71\%) au prezentat malformaţii minore cu sau fără malformaţii majore asociate. Astfel, s-au examinat 19 pacienţi $(16 \%)$ care prezentau o singură malformaţie minoră, 34 de pacienţi $(29 \%)$ care au prezentat 2 malformaţii minore şi 31 de pacienţi $(26 \%)$ care au prezentat 3 sau mai multe anomalii congenitale minore (Tabel 2).

Distribuţia pacienţilor în funcţie de sindromul genetic a fost: cei mai mulţi pacienţi, 73 (86\%), cu anomalii minore oculare au fost cei cu sindrom Down, 7 pacienţi cu neurofibromatoză tip 1 (8\%), 2 pacienţi cu sindromul blefarofimozei (2\%), 1 pacient cu sindromul Schwartz-Jumpel (1\%) şi 1 cu fibroza congenitală a muşchilor extraoculari (1\%).

TABEL 2. Frecvența de asociere a malformațiilor oculare minore

\begin{tabular}{|l|c|c|}
\hline $\begin{array}{l}\text { Nr. malformații } \\
\text { minore }\end{array}$ & $\begin{array}{c}\text { Nr. } \\
\text { pacienți }\end{array}$ & $\%$ \\
\hline 1 malformație minoră & 19 & 16 \\
\hline 2 malformații minore & 34 & 29 \\
\hline$\geq 3$ malformații minore & 31 & 26 \\
\hline Total & 84 & $71 \%$ \\
\hline
\end{tabular}

\section{DISCUȚII}

Examenul oftalmologic trebuie efectuat de la 6 luni sau chiar de la naştere atunci când acesta poate aduce un aport considerabil diagnosticului de sindrom sau boală genetică. Este evidentă necesitatea studiului unor markeri obiectivi care să faciliteze un diagnostic mai rapid pentru clinician şi să reducă complicaţiile [6].

Categoria de vârstă peste 15 ani a fost cel mai bine reprezentată $(43 \%)$ deoarece este şi vârsta la care complianţa şi adresabilitatea pacienţilor cu boală genetică şi aparţinătorilor acestora creşte. Rezultatul a fost similar celor prezentate în literatura de specialitate de către Schneider şi colab. [7] şi Collins şi colab. [8]. Chuka-Osaka şi colab. au afirmat, într-un studiu realizat pe pacienţi cu anomalii minore şi majore oculare, că severitatea malformaţiilor influenţează vârsta de diagnosticare a anomaliilor congenitale oculare [9].

Cel mai frecvent sindrom genetic prezent în studiu a fost sindromul Down, acesta fiind şi cea mai frecventă anomalie cromozomială genetică la nivel global [10-12]. Rezultatul este în concordanţă cu studiul realizat de Bermejo şi Martinez-Frias [13], unde numărul mare de anomalii oculare a fost datorat unui număr mare de cazuri de trisomie 21 .

Anomaliile oculare minore sau simple au fost prezente la un număr mare de pacienţi şi în studiul realizat de Marzouk şi colaboratorii [14].

În studiul actual, s-a observat că anomaliile oculare minore au fost multiple în $71 \%$ dintre cazuri, rezultat cu o deosebită valoare practică. Astfel, ori de câte ori se identifică o anomalie minoră, se impune căutarea altora.

Malformaţiile palpebrale reprezintă criterii de diagnostic pentru trisomia 21. Dat fiind numărul mare de pacienţi cu acestă anomalie cromozomială, pleoapa a fost anexa oculară universal afectată în toate studiile efectuate la aceşti pacienţi $[15,16]$. Studiul realizat de Arora şi colab. a demonstrat, de asemenea, că, din punct de vedere anatomic, malformaţiile palpebrale şi de poziţie reprezintă cele mai frecvente anomalii oculare [17]. Anomaliile prezente la acest nivel sunt anomalii minore, însă de o mare utilitate pentru diagnosticul de sindrom. Fantele palpebrale oblice reprezintă cea mai frecventă anomalie la pacienţii cu sindrom Down prezentă atât în studiul nostru, cât şi în majoritatea studiilor realizate [18]. Prevalenţa acestei anomalii în studiul actual este uşor mai scăzută faţă de cea întâlnită de Scherbenske şi colab., $65 \%$ vs. $80 \%$ [19].

Componenta oculară care a prezentat cel mai adesea modificări a fost irisul. Morrison a descris în studiul său importanţa examinării irisului în patologia genetică. Acesta a menţionat că o examinare minuţioasă a acestuia poate să fie fereastra pentru cele mai comune şi rare boli genetice [20].

Petele albicioase dispuse concentric la periferia medie a irisului au fost descrise de Brushfield în 1924 la pacienţii cu sindrom Down cu iris de culoare deschisă. Prevalenţa acestora în studiul actual a fost de $16 \%$, rezultat concordant cu studiile realizate în Asia sau pe un lot cu un număr mare de pacienţi cu iris de culoare închisă $[21,22]$. 
Postolache şi colaboratorii susţin că examinarea irisului de culoare închisă folosind lumina infraroşie creşte rata de detecţie a acestora de la $21 \%$ la cei examinaţi cu lumina albă până la $65 \%$ [23].

Nodulii Lisch au fost prezenţi la 5 dintre cei 7 pacienţi cu boală autozomal dominantă. Spre deosebire de petele Brushfield, care au fost descrise de Wölfflin şi la pacienţi fără boală genetică, nodulii lui Lisch sunt prezenţi în procent de $90 \%$ doar la pacienţi adulții cu neurofibromatoză tip I [24,25].

Prezenţa vaselor supranumerare sau vasele cu aspect de spiţe de roată este o anomalie minoră prezentă la pacienţii cu sindrom Down. Willliams şi colaboratorii au fost primii care au menţionat în 1973 prezența unui număr crescut de vase la nivelul discului optic la mongoloizi [26]. Această malfomaţie minoră a fost certificată şi Sherk şi colab., aceştia adăugând că acesta este prezentă independent de patologia cardiacă [27].

\section{BIBLIOGRAFIE}

1. Costa T, Scriver R.C, Childs B. The Effect of Mendelian Disease on Human Health: A Measurement. American Journal of Medical Genetics. 1985;21:231-242.

2. Traboulsi E. Genetic Diseases of the Eye. 2nd Edition. Oxford University Press 2012:190-245.

3. Bembea M. Genetica în pediatrie. Cluj-Napoca. Risoprint, 2016:97-113.

4. Askin DF. Physical assessment of the newborn: minor congenital anomalies. Nurs Womens Health. 2009;13(2):140-8.

5. Adam $M$, Hudgins $L$. The importance of minor anomalies in the evaluation of the newborn. NeoReviews. 2003;4(4):e99-104.

6. Tomairek RH, Amin MM, Raafat K, Abdel Hady S, Elkotoury A. Prevalence of Congenital Ocular Anomalies among Children with Genetic Disorders: An Egyptian Study. Semin Ophthalmol. 2018; 33(5):613-619.

7. Schneider KI, Schimdtke J. Patient Compliance Based on Genetic Medicine: A Literature Review. J Community Genet. 2014;5(1):31-48.

8. Collins RE, Wright AJ, Marteau TM. Impact of communicating personalized genetic risk information on perceived control over the risk: a systematic review. Genet Med. 2011;13(4):273-7.

9. Chuka-Okosa CM, Magulike NO, Onyekonwu GC. Congenital eye anomalies in Enugu, South-Eastern Nigeria. West Afr J Med. 2005; 24(2):112-4.

10. Kazemi M, Salehi M, Kheirollahi M. Down Syndrome: Current Status, Challenges and Future Perspectives. Int J Mol Cell Med. 2016; 5(3):125-133.

11. Murthy SK, Malhotra AK, Mani S, Shara ME, Al-Rowaished EE, Naveed S, Alkhayat Al, Alali MT. Incidence of Down syndrome in Dubai, UAE. Med Princ Pract. 2007;16(1):25-8.

12. Malt EA, Dahl RC, Haugsand TM, Ulvestad IH, Emilsen NM, Hansen B, Cardenas YE, Skøld RO, Thorsen AT, Davidsen EM. Health and disease in adults with Down syndrome. Tidsskr Nor Laegeforen. 2013;133(3):290-4

13. Bermejo E, Martínez-Frías ML. Congenital eye malformations: clinical-epidemiological analysis of 1,124,654 consecutive births in Spain. Am J Med Genet. 1998;75(5):497-504.

14. Marzouk IM, Elshakankiry NM, Ibrahim AG, Anwar SAM, Awadallah SM. Registry of ocular anomalies among patients with genetic
Parsa şi colab. susţin că prezenţa vaselor supranumerare reprezintă un factor protector pentru angiogeneză în cazul pacienţilor cu sindrom Down cu retinopatie diabetică sau cu tumori solide. Această particularitate se datorează unui nivel crescut de endostatină, o proteină codată la nivelul cromozomului 21 , cu rol în inhibarea angiogenezei [28].

\section{CONCLUZII}

Anomaliile oculare congenitale minore, chiar dacă nu sunt de gravitate, constituie deseori elemente sugestive pentru anumite sindroame genetice. Identificarea lor trebuie inclusă în protocolul de diagnostic al oricărei suspiciuni de boală genetică. Indiferent de boala genetică, din punct de vedere anatomic, pleoapa a fost anexa oculară care ne-a oferit mereu indicii „minore“ cu un important răsunet diagnostic.

Conflict of interest: none declared Financial support: none declared

disorders in Alexandria and nearby governorates. Alexandria Journal of Pediatrics 2019;32(1):55-60.

15. Kim JH, Hwang JM, Kim HJ, Yu YS. Characteristic ocular findings in Asian children with Down syndrome. Eye (Lond). 2002;16(6):710-4.

16. Caputo AR, Wagner RS, Reynolds DR, Guo SQ, Goel AK. Down syndrome. Clinical review of ocular features. Clin Pediatr (Phila). 1989; 28(8):355-8

17. Arora P, Tullu MS, Muranjan MN, Kerkar SP, Girisha KM, Bharucha BA. Congenital and inherited ophthalmologic abnormalities. Indian J Pediatr. 2003;70(7):549-52.

18. Eissler R, Longenecker LP. The common eye findings in mongolism. Am J Ophthalmol. 1962;54:398-406.

19. Scherbenske JM, Benson PM, Rotchford JP, James WD. Cutaneous and ocular manifestations of Down syndrome. J Am Acad Dermatol. 1990;22(5Pt2):933-8.

20. Morrison PJ. The iris - a window into the genetics of common and rare eye diseases. Ulster Med J. 2010;79(1):3-5.

21. Fimiani F, lovine A, Carelli R, Pansini M, Sebastio G, Magli A. Incidence of ocular pathologies in Italian children with Down syndrome. Eur J Ophthalmol. 2007;17(5):817-22.

22. Fong AH, Shum J, Ng AL, Li KK, McGhee S, Wong D. Prevalence of ocular abnormalities in adults with Down syndrome in Hong Kong. $\mathrm{Br}$ J Ophthalmol. 2013;97(4):423-8.

23. Postolache, L, Parsa, CF. Brushfield spots and Wölfflin nodules unveiled in dark irides using near-infrared light. Sci Rep. 2018;8:18040.

24. Daoudi C, Daoudi R. Lisch nodules in Von Recklinghausen disease. Pan Afr Med J. 2014;19:173.

25. Maharaj A, Singh VR, Lalchan SA. Lisch and the Importance of His Nodules. West Indian Med J. 2014;63(7):799-802.

26. Williams EJ, McCormick AQ, Tischler B. Retinal vessels in Down's syndrome. Arch Ophthalmol. 1973;89(4):269-71.

27. Sherk MC, Williams TD. Disc vascularity in Down's syndrome. Am J Optom Physiol Opt. 1979;56(8):509-11.

28. Parsa CF, Almer Z. Supranumerary optic disc vessels may indicate reduced systemic angiogenesis in Down syndrome. Br J Ophthalmol. 2008;92(3):432-3. 